\title{
Cerebral Abnormalities in Diabetes Mellitus: An Ultrastructural Study of the Brain in Early Onset Diabetes Mellitus in the Chinese Hamster*
}

\author{
Sarait A. Luse, Georgen C. Gerritsein and Wirliam E. Dulin \\ Department of Anatomy; College of Physicians and Surgeons of Columbia University, New York, New York and The \\ Upjohn Company, Kalamazoo, Michigan, USA
}

Summary. Brains of diabetic chinese hamsters have been compared with those of normal controls of the same age and sex. By electron microscopy vascular lesions were prominent, especially thickening and reduplication of basement membranes. Neurons were markedly altered with 1. Megamitochondria in dendrites, 2. densely fibrillar axoplasm, 3. degenerating axons and dendrites, 4. focal myelin degradation and 5 . degeneration of - synaptic endings on nerve cell stroma.

Modifications cérébrales diabétiques: étude de l’ultrastructure du cerveau d'hamsters chinois diabétiques

Résumó. Das coupes de cervaux d'hamster chinois ont été comparies avec celles d'animaux témoins du même âge et sexe. Les lésions vasculaires observées au microscope électronique sont prononcées, comportant surtout des épaississements et tortuosités de la membrane basale. On observe en outre des altérations marquées des neurones: 1. présence de mégamitochondries dans les dendrites, 2. axoplasmes fibrillaires denses, 3 . axons et dendrites en dégénérescence, 4. dégradation myélinique focale et 5. dégénérescence des terminaisons synaptiques du stroma des cellules nerveuses.
Gehirnveränderungen beim Diabetes Mellitus: eleltronenmikroskopische Untersuchungen am Gehirn , ,juvenil diabetischer chinesischer Hamster

Zusammenfassung. Vergleichende elektronenmikroskopische Untersuchungen am Hirngewebe normaler und diabetischer chinesischer Hamster gleichen Alters und Geschlechts ergaben folgende Resultate: deutliche vasculäre Veränderungen, vor allem eine Verdickung und Faltung der Basalmembran. Außerdem wiesen die Neurone gegenüber der Norm folgende Abweichungen auf: 1 . Vorhandensein von Megamitochondrien in den Dendriten, 2. dicht fibrilläres Axoplasma, 3. degenerierende Axone und Dendriten, 4. fokale Zersetzung des Myelins und 5. Degeneration synaptischer Endstellen am Nervenzellstroma.

Key-words: Diabetes mellitus, diabetes in animals, brain in diabetes, microangiopathy, chinese hamster, Cricetulus griseus, ultrastructure of brain, central pathology in diabetes.
Since 1959 when a severe hereditary abnormality in carbohydrate metabolism in the chinese hamster was reported by Meier and Yerganian [8] many parameters of diabetes mellitus have been explored in this species. Although pathologic alterations in the islets of Langerhans $[2,7]$ and in the renal glomerulus [11] have been studied in detail, little if any attention has been given to the nervous system. It is the purpose of this paper to present ultrastructural changes in the brains of early onset diabetic chinese hamsters as compared with nondiabetic controls of the same sex and age.

\section{Materials and Methods}

Three diabetic hamsters and 3 non-diabetic controls of the same sex and age from the Upjohn colony were killed by exsanguination (Table). The cranium was rapidly removed, and a segment of the central part of the right cerebral hemisphere rapidly excised and minced in cold Dalton's chromeosmium fluid. Blocks were fixed $\mathbf{1 - 2} \mathbf{h}$, dehydrated in a graded series of ethanol, and embedded in Durcupan (Swiss Araldite). Polymerization was $48-96 \mathrm{~h}$ at $60^{\circ} \mathrm{C}$. Thin sections

* This work was supported in part by a grant (NB 07887) from the Institute of Neurological Diseases and Stroke, NIH, Bethesda, Maryland and by a grant from the Upjohn Company. were cut with a diamond knife and a MT-1 microtome, stained with lead citrate and examined in an RCA EMU-3H electron microscope.

\section{Observations}

Cerebral cortex from the brains of the 3 non-diabetic control animals was normal by electron microscopy. Basement membranes about capillaries and arterioles were thin. No evidence of degenerative changes could be seen. In contrast to the normal ultrastructure of the control brains, cerebral cortex from all of the diabetic animals showed a variety of abnormalities.

Blood vessels in brains of diabetic animals had three distinct types of lesions. About some vessels, especially arterioles, there were accumulations of electron-dense material (Fig: 1). Some cells were distinguished from smooth muscle with difficulty. Others could be macrophages or the so-called pericytes. The electron-dense material in part of them may be lipid, and in part the remnants of lipid digestion, namely, lysosomes. About many vessels, especially capillaries, there was a perivascular extension of an amorphous electron-dense material that extended out between the closely packed perivascular glial processes. The third vascular lesion was a marked thickening and reduplication of basement membrane (Fig. 2). Such 


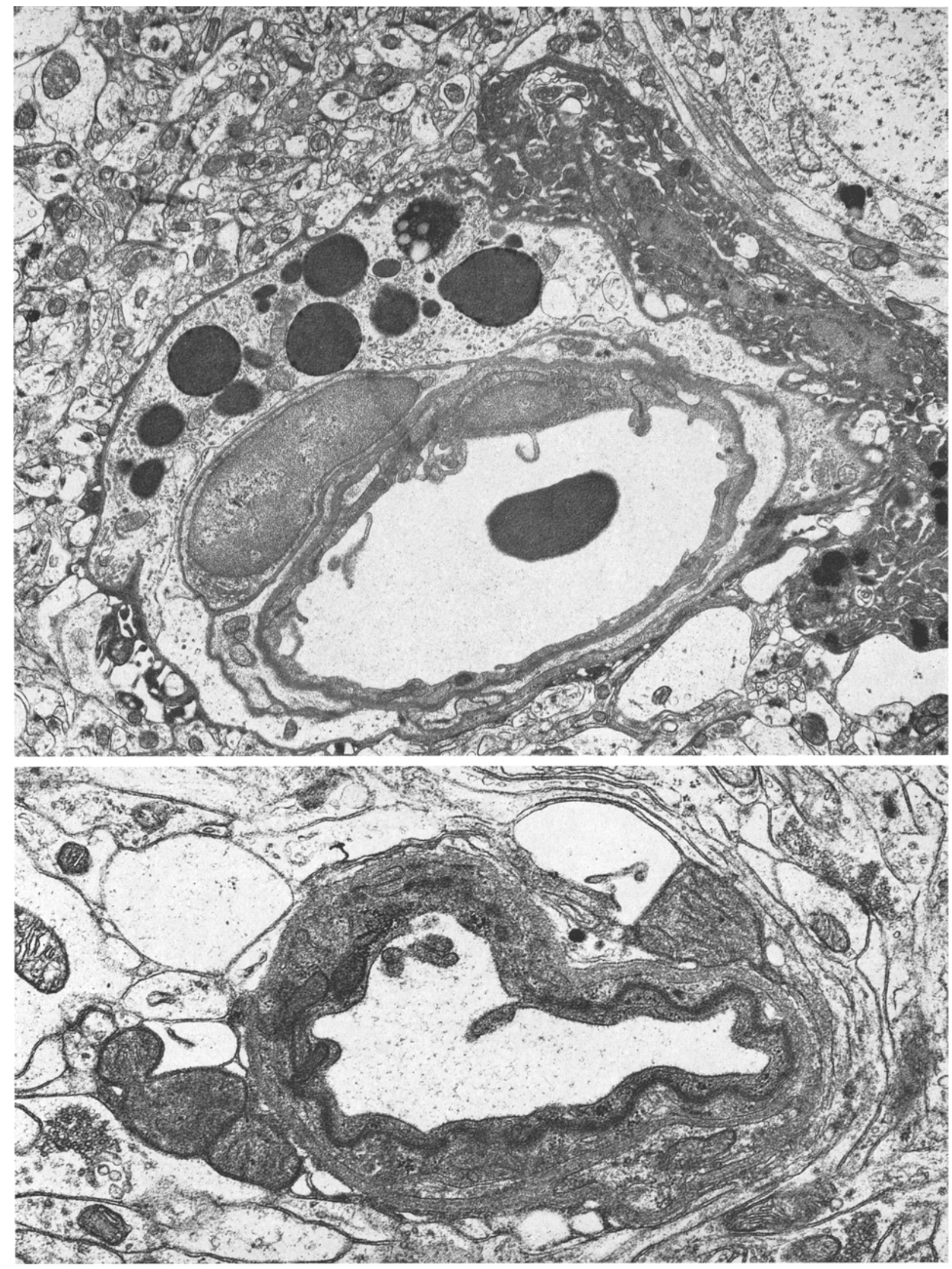

Fig. 1. Small arteriole in cerebral cortex of diabetic hamster. Numerous lipid droplets and lysosomes are present in cytoplasm of outermost perivascular cell. This cell is enclosed by basement membrane and may represent an altered smooth muscle cell. Part of a dense microglial cell is present at the right. $\times 8000$

Fig. 2. Another cerebral blood vessel in a diabetic hamster. The thickened wall of this tiny vessel is obvious. $\times 20000$ 


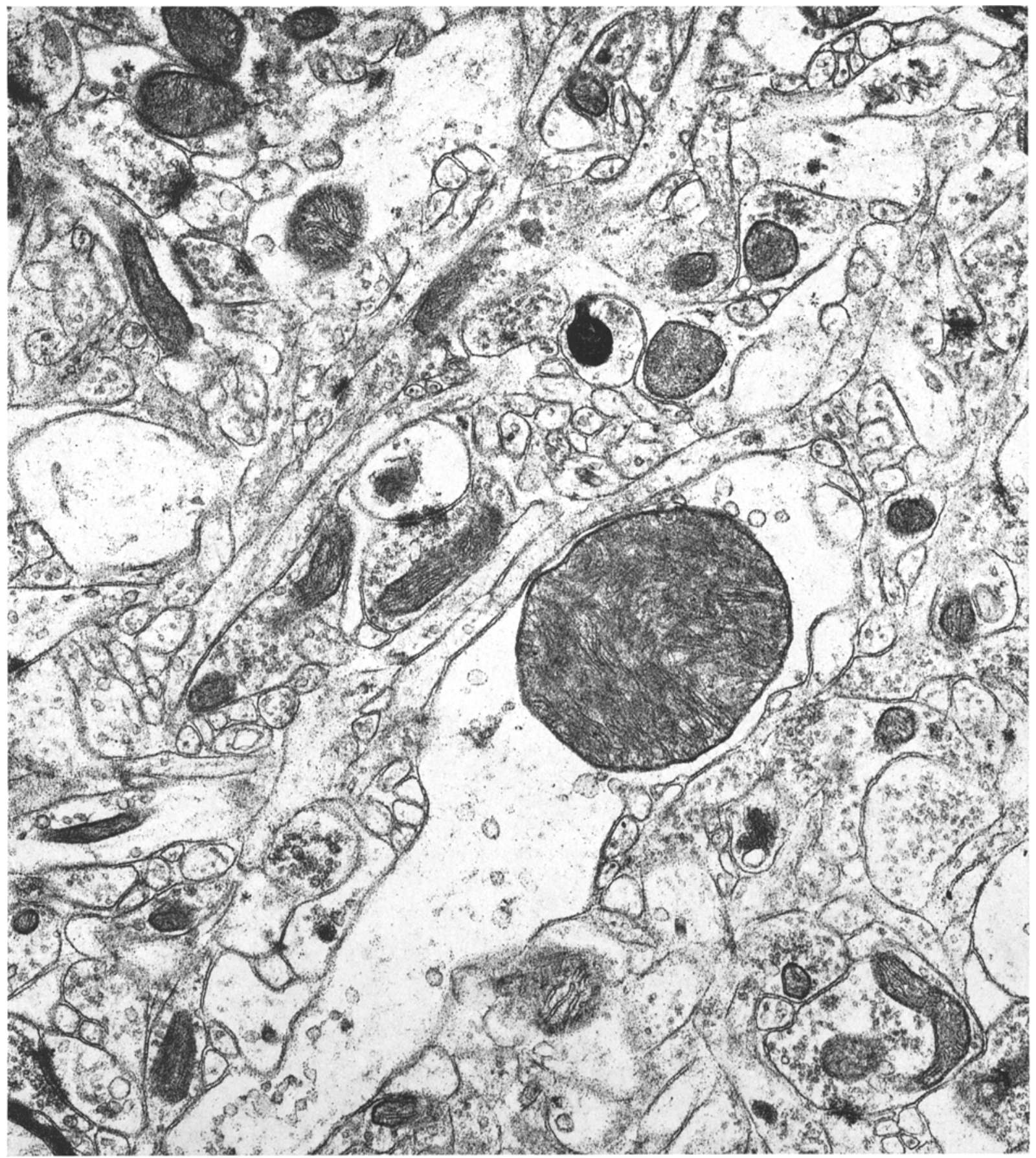

Fig. 3. Cerebral cortex of diabetic hamster. A huge mitochondrion in a neurite is present in the centre of the maicrograph. Cristae are somewhat indistinct and intertwined although "the membranes are crisp. The relative size of this mitochondrion is evident when it is compared with usual sized organelles in adjacent processes. Synapses are numerous. $\times 22000$

extensive thickening of the wall of a small cortical vessel was never seen in the control animals. It was more frequent and more marked in the oldest of the diabetic hamsters examined.
Mitochondrial abnormalities were observed in all three diabetic hamsters. Mitochondria in neurite processes, especially in dendrites (Fig. 3 and 4 ) were hypertrophied. These megamitochondria were packed 


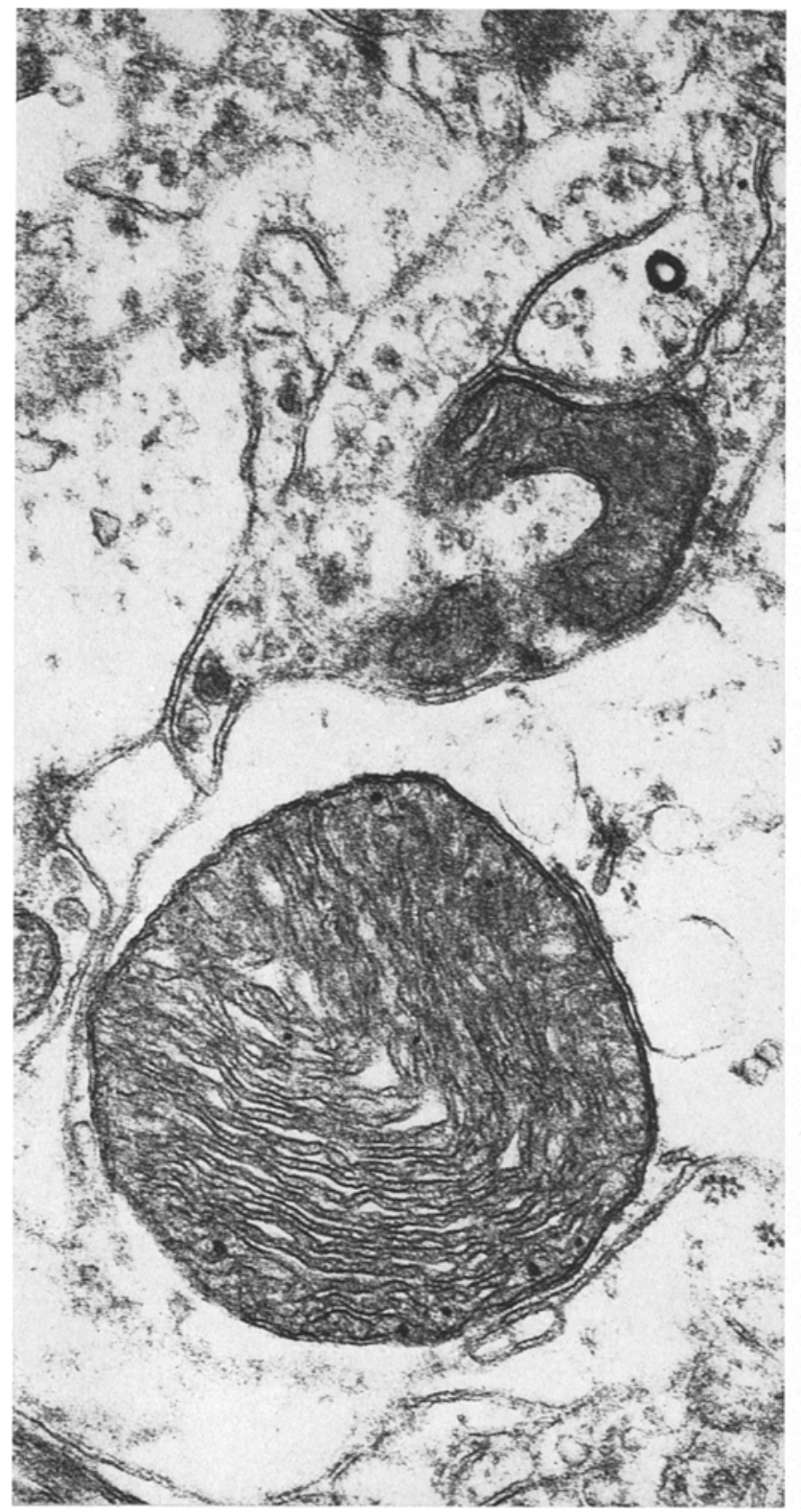

Fig. 4. Another giant mitochondrion in a dendrite. The cristae are of unusual configuration for cerebral cortex. $\times 45000$

Table

\begin{tabular}{|c|c|c|c|c|c|}
\hline & Sex & $\begin{array}{l}\text { Date of } \\
\text { birth }\end{array}$ & Diabetic & Kototic & Killed \\
\hline $\begin{array}{l}\text { Diabetic } 1 \\
\text { F } 2-3\end{array}$ & 움 & $6 / 7 / 68$ & $6 / 22 / 68$ & $9 / 22 / 68$ & $4 / 17 / 69$ \\
\hline $\begin{array}{l}\text { Control } 1 \\
\mathrm{~Pa}-11-15\end{array}$ & 우 & $6 / 25 / 68$ & - & - & $4 / 17 / 69$ \\
\hline $\begin{array}{l}\text { Diabetic } 2 \\
\times 2-7\end{array}$ & 우 & $12 / 12 / 67$ & $1 / 7 / 68$ & $3 / 7 / 68$ & $4 / 17 / 69$ \\
\hline Control 2 & 우 & $12 / 18 / 67$ & - & - & $4 / 17 / 69$ \\
\hline $\begin{array}{l}\text { Diabetic } 3 \\
\text { W } 2-43\end{array}$ & o & $10 / 21 / 67$ & $10 / 22 / 67$ & $5 / 7 / 68$ & $4 / 17 / 69$ \\
\hline $\begin{array}{l}\text { Control } 3 \\
\mathrm{Pg} 7-17\end{array}$ & $\sigma^{\pi}$ & $10 / 16 / 67$ & - & - & $4 / 17 / 69$ \\
\hline
\end{tabular}

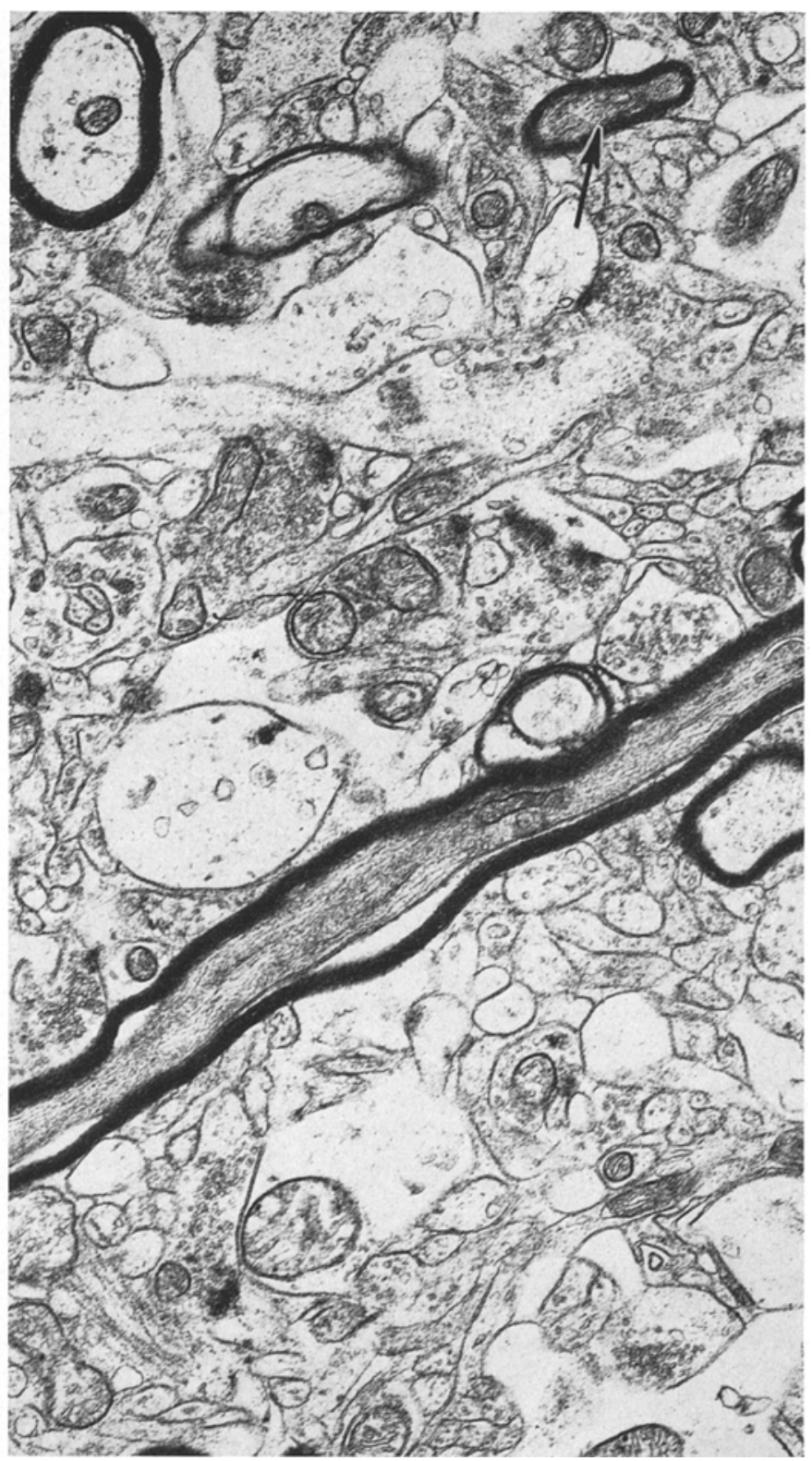

Fig. 5. A longitudinally-sectioned myelinated axon is somewhat shrunken and of increased electron density. A similar but smaller axon is seen at the arrow. Their abnormal axoplasm is in contrast to the normal axon at the upper right. $\times 12000$

with cristae. In others almost no cristae could be recognized, representing either a tangential section or an end-stage.

Axons were in various stages of degeneration. Some had an axoplasm with an increase in fibrillar content (Fig. 5). Others showed outright axoplasmic degeneration of the surrounding myelin sheath. Large unmyelinated nerve processes (Fig. 6 and 7) were also in the midst of a degenerative process. They were expanded in cross-section and contained an excess of both mitochondria and lysosomes. Elsewhere in the shite 


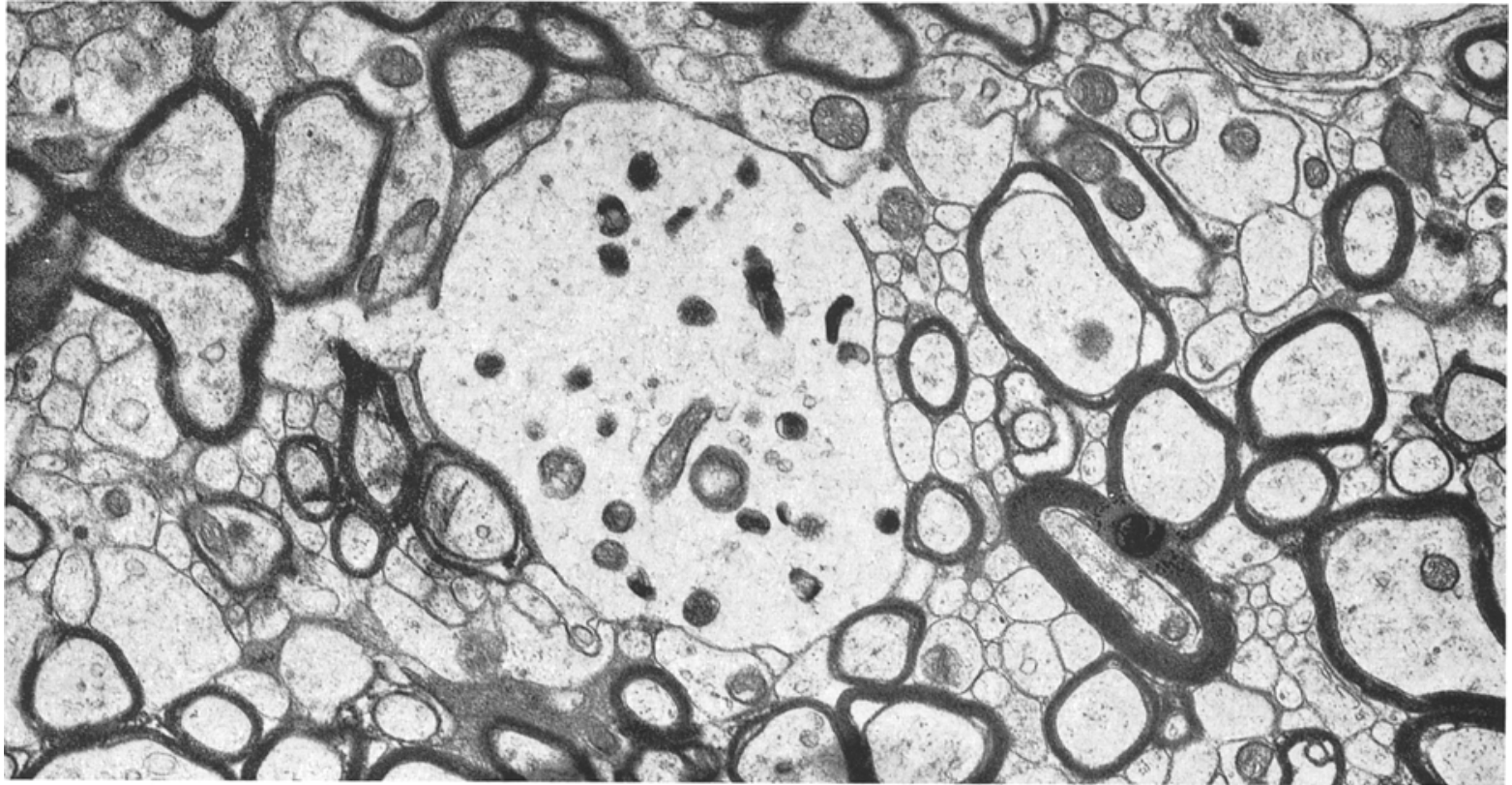

Fig. 6. Degenerating neurite process. Lysosomes and an increased number of mitochondria fill this expanded process. $\times 12000$

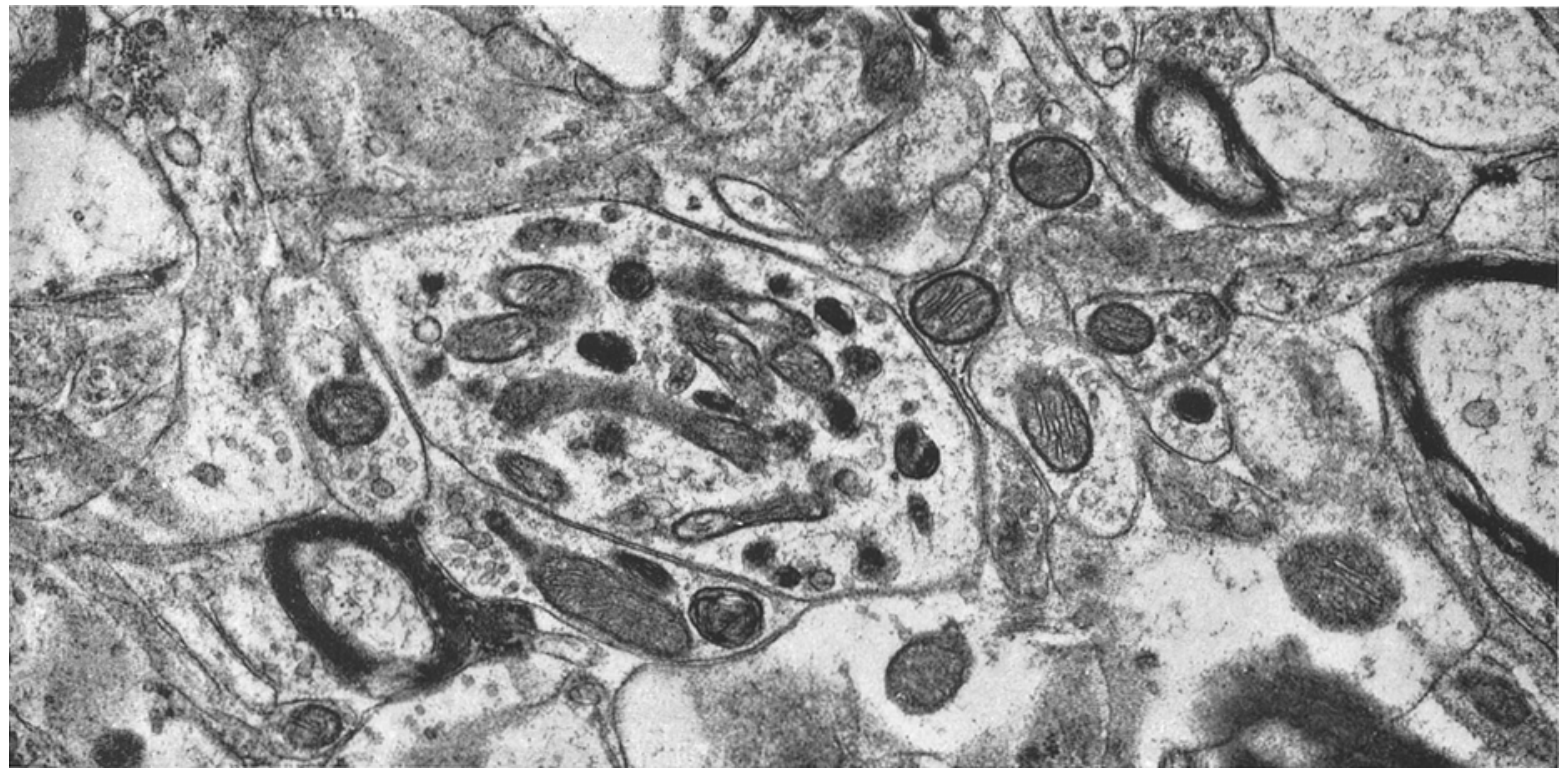

Fig. 7. Low magnification of another degenerating neurite. Its considerable increase in diameter is obvious in comparison with the adjacent unmyelinated processes. Lysosomes are prominent. $\times 15000$

matter "holes" were present (Fig. 8), which represent the space previously occupied by processes such as those seen in Figs. 6 and 7. This is a common reaction to loss of a nerve cell or process. Other such spaces perhaps resulted from the remains of disintegrated myelin.

Many axonal terminals contained small lysosomes. Some synaptic endings on the neuronal soma appeared as an empty shell that still indented the surface of the neuron. In some (Fig. 9), a few small synaptic vesicles remained. Often the zone of attachment remained but appeared abnormal (Fig. 9).

\section{Discussion}

Vague and scattered references to pathologic alterations in the brains of human diabetics have been cited in the diabetic literature. Morphologic changes men- 


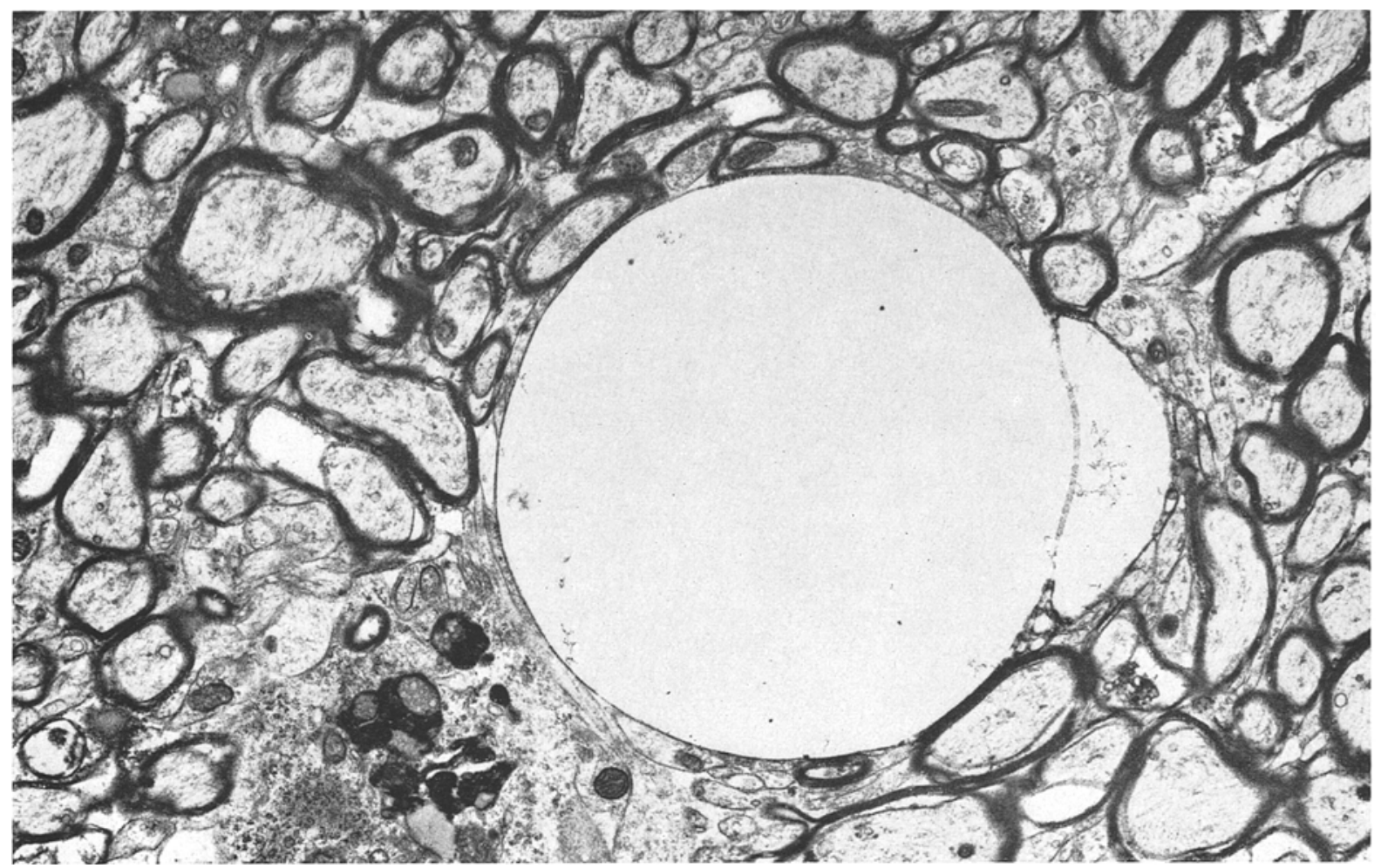

Fig. 8. Residual space in white matter after loss of a degenerated neurite process. $\times 15000$

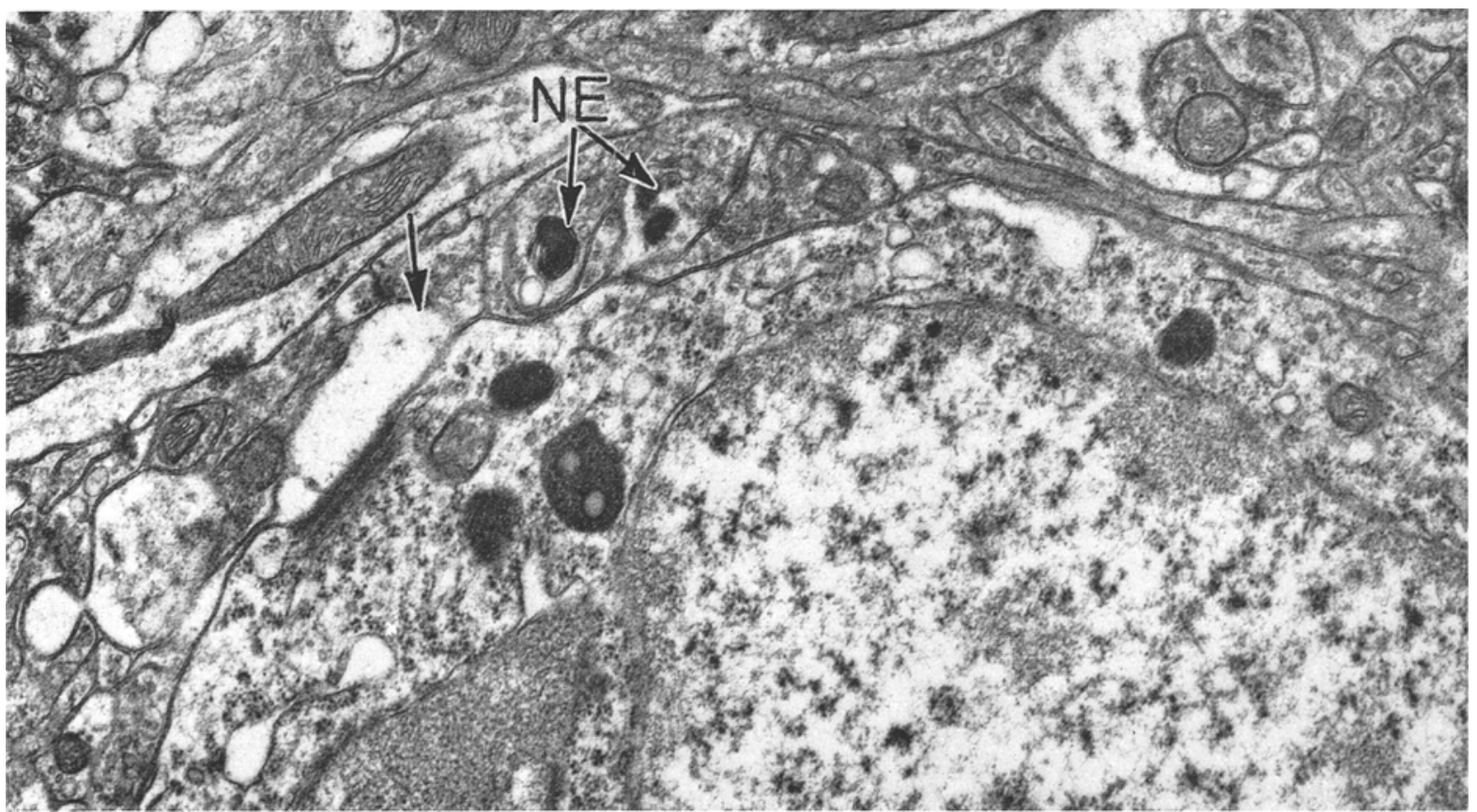

Fig. 9. The nucleus and cytoplasm of cortical neuron are present at the lower left. Several axons nearing their endings indent the surface of the axon (NE). They contain synaptic vesicles and dense bodies that probably represent lysosomes. Above these processes there is an empty membrane enclosed space that is continuous (arrow) with a small zone containing synaptic-type vesicles. A dense zone is present along part of the membrane-contact zone suggesting that this may be an abnormal synaptic ending. $\times 22000$ 
tioned have included glycogen in the perivascular space and in pyramidal cells, dilated blood vessels and glial proliferation; all changes that could be considered non-specific. DeJong [3] was the first to implicate the central nervous system as being involved in severe diabetes mellitus. More recently Olsson, et al. [9] Lapresle [6] and Resko-Nielsen and Lundbaek [10] have reported in some detail on central nervous system lesions in diabetes, especially on perivascular changes. At the light microscopic level, however, the dramatic degree of involvement of the brain has been unsuspected.

The questions of interpretation of our findings and the questions of pathogenesis remain to be resolved. Gottstein \& Held [11] have been concerned with the effects of insulin on cerebral glucose uptake. Butterfield et al. [1] have suggested that the brain is insulin sensitive and that in the diabetic brain glucose uptake is reduced. Flock et al. [4] also have been concerned with glucose concentrations in the brains of diabetic rats, although their data are difficult to interpret in regard to ours since theirs were acute experiments.

Acknowledgements: The authors wish to acknowledge the skillful technical assistance of Mrs. Helen Mantullin.

\section{References}

1. Butterfield, W.J.F., Abrams, M.E., Sells, R.A., Sterky, G., Whichelow, M.J.: Insulin sensitivity of the human brain. Lancet 1966 I, $557-560$.

2. Carpenter, A.M., Gerritsen, G.C., Dulin, W.F., Lazarow, A.: Islets and Beta cell volumes in diabetic Chinese Hamsters and their non-diabetic siblings. Diabetologia 3, $92-96$ (1967).
3. DeJong, R.N.: The nervous system complications of diabetes mellitus with special reference to cerebrovascular changes. J. nerv. ment. Dis. 111, 181-206 (1950).

4. Flock, E.V., Tyce, G.M., Owen, C.A., Jr.: Glucose metabolism in brains of diabetic rats. Endocrinology $85,428-437$ (1969).

5. Gottstein, U., Held, K.: Insulinwirkung auf den menschlichen Hirnmetabolismus von Stoffwechselgesunden und Diabetikern. Klin. Wschr. 45, 18-23 (1967).

6. Lapresle: Les lesions cérébrales au cours du diabète sucré. Arch. Anat. path. 29, 1-6 (1953).

7. Luse, S.A., Caramia, F., Gerritsen, G., Dulin, W.E.: Spontaneous diabetes mellitus in the Chinese Hamster: An electron microscopic study of the islets of Langerhans. Diabotologia 3, 97-108 (1967).

8. Meier, H., Yerganian, G.E.: Spontaneous hereditary diabetes mellitus in Chinese hamster. Pathological findings. Proc. Soc. exp. Biol. 100, 810-815 (1959).

9. Olsson, Y., Save-Söderbergh, J., Sourander, P.; Angervall, L.: A patho-anatomical study of the central and peripheral nervous system in diabetes of early onset and long duration. Path. europ. 3, 62-79 (1968).

10. Reske-Nielsen, E., Lundbaek, K.: Diabetic Encephalopathy. Diffuse and focal lesions of the brain in long-term diabetics. Acta neurol. scand. Suppl. 4, $273-290$ (1964).

11. Shirai, T., Welsh, G.W., Sims, E.A.H.: Diabetes mellitus in the Chinese hamster. Diabetologia 3, $266-286$ (1967).

Dr. Sarah A. Luse

Dept. of Anatomy

College of Physicians and

Surgeons of Columbia University

164th St. W.

New York, N.Y. 10025, USA 